\title{
Interventions supporting the integration of refugee children in the primary school life: Roles of the child's contexts of development
}

\begin{tabular}{|c|c|}
\hline \multicolumn{2}{|c|}{$\begin{array}{l}\text { Authors: } \\
\text { Rasheedah O. } \\
\text { Adams-Ojugbele }{ }^{1} \\
\text { Nontokozo Mashiya }^{1}\end{array}$} \\
\hline \multicolumn{2}{|c|}{$\begin{array}{l}\text { Affiliations: } \\
\text { 'Department of Early } \\
\text { Childhood Education, } \\
\text { Faculty of Education, } \\
\text { University of Kwazulu-Natal, } \\
\text { Durban, South Africa }\end{array}$} \\
\hline \multicolumn{2}{|c|}{$\begin{array}{l}\text { Corresponding author: } \\
\text { Rasheedah Adams-Ojugbele, } \\
\text { adamrasheedat@yahoo.com }\end{array}$} \\
\hline \multicolumn{2}{|c|}{$\begin{array}{l}\text { Dates: } \\
\text { Received: } 17 \text { Oct. } 2019 \\
\text { Accepted: } 08 \text { July } 2020 \\
\text { Published: } 05 \text { Nov. } 2020\end{array}$} \\
\hline \multicolumn{2}{|c|}{$\begin{array}{l}\text { How to cite this article: } \\
\text { Adams-Ojugbele RO, } \\
\text { Mashiya N. Interventions } \\
\text { supporting the integration } \\
\text { of refugee children in the } \\
\text { primary school life: Roles } \\
\text { of the child's contexts of } \\
\text { development. J transdiscipl } \\
\text { res S Afr. 2020;16(1), a769. } \\
\text { https://doi.org/10.4102/ } \\
\text { td.v16i1.769 }\end{array}$} \\
\hline \multicolumn{2}{|c|}{$\begin{array}{l}\text { Copyright: } \\
\text { @ 2020. The Authors. } \\
\text { Licensee: AOSIS. This wo } \\
\text { is licensed under the } \\
\text { Creative Commons } \\
\text { Attribution License. }\end{array}$} \\
\hline \multicolumn{2}{|l|}{ Read online: } \\
\hline 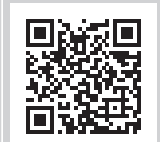 & $\begin{array}{l}\text { Scan this QR } \\
\text { code with your } \\
\text { smart phone or } \\
\text { mobile device } \\
\text { to read online. }\end{array}$ \\
\hline
\end{tabular}

The development of children in an atmosphere that supports and promotes their socioemotional, physical and cognitive well-being is imperative for the realisation of the sustainable development goal 4 for 2030. The school environment constitutes an important context where children learn and acquire both social and academic skills, through their interaction with adults and peers, materials and objects in their immediate environment. The aim of this article was to advance the debate on studies focussing on intervention programmes that support the school adjustment of refugee children in primary schools in host countries. Specifically, the article focussed on analysing the available school-based intervention programmes for refugee children in the primary school life. The article utilised the integration theory and the bioecological model of human development as lenses for analysis. The article picked on selected empirical articles and reviews for inclusion in the analysis. Findings from the analysis indicate that the primary school experiences of refugee children in different parts of the world are complex and vary. Whilst some refugee children enjoy inclusion in the primary school life, others are faced with varied challenges, which might impact negatively on their successful integration and adjustment into the school system. This article advocates for an inclusive intervention, where the different persons and contexts involved in the social and academic integration of refugee children interact in a manner that promotes and supports the specific social and developmental needs of refugee children for a favourable outcome.

Keywords: refugee children; school experience; intervention programmes; social interaction; integration; child development.

\section{Background}

The high increase in the influx of asylum seekers and refugee population to different parts of the world is alarming. Recent statistics indicated that more than $70.8 \mathrm{~m}$ people have been forced to flee their countries of residence, with almost $25.9 \mathrm{~m}$ constituting refugee population and over half of these population under the age of $18 .{ }^{1}$ On this basis, the international legal frameworks made provisions for the refugee's right to basic primary education, health and housing, including social welfare support by government of the host countries. ${ }^{2}$ South Africa is no exception. As a member of the Southern African Development Community (SADC), the South African government signed the United Nations 1951 Convention on the Status of Refugees, and the 1969 Africa Refugee Convention Act as such is saddled with the responsibility of protecting anyone who, because of the fear of being persecuted or as a result of conflict, natural disaster or civil strife, flee their countries of residence to seek asylum in other countries. ${ }^{3,4}$ Consequently, they are faced with the responsibility of 'achieving development and economic growth, alleviating poverty, enhancing the standard and quality of life of the peoples of Southern Africa, and supporting the socially disadvantaged through regional integration'. ${ }^{3}$

In spite of this recognition and responsibilities placed on individual countries based on both the national and international legal frameworks, children from the refugee background tend to be on the margins of society, and because of difficulties around documentation and access to other services including education, social welfare and health, their successful integration into the host countries proves to be challenging. ${ }^{5,6}$ Regardless of the reasons for migration, generally, the refugee population continue to experience a host of challenges and continue to struggle for survival in their countries of first asylum and/or host country. ${ }^{7,9}$

The challenges faced by these population continue to expose them to situations that are difficult and pose a host of risks to their survival including their children's, in the alien 
environments. Based on the foregoing, this article focusses on analysing the social intervention programmes, which assist refugee children to successfully adapt into the social life of the primary school. In this article, refugees will be referred to generally as a person/s who seeks asylum and awaiting his or her permit, which will give them a refugee status, as well as those who have been granted their refugee status to continue their stay in the country. ${ }^{2,10}$

The focus of this article is to examine the available intervention that supports the social integration of refugee children into the foundation phase school life, whilst paying attention to the role played by the child's contexts of development. We present a background to refugee children's life experience and the circumstances surrounding their stay in the host countries. Then, we picked at random empirical studies that focus on the social and educational challenges combating the refugee children in public primary schools of their host countries. Peer-reviewed articles across the United States and Europe, including some from southern African countries, were included for review. There were no strict timelines for the publication of articles included but, effort was made to ensure that articles before the year 2010 were not included for review except in situations where no alternatives were available.

The realities surrounding the social adaptation of refugee children in their various host countries across the globe are yet to be fully captured in literature and empirical studies. Research evidence suggests that refugee children are at risk of not accessing quality educational programmes, including social and health services on their arrival in the host country and therefore face a host of challenges of integrating effectively into the life of their new environment. ${ }^{9,11,12,13}$ The past experiences and conditions of the refugee children in their countries before and during their migration have exposed them to such situations that serve as deterrent to their successful adaptation in their new environment. For the challenges stated here, the refugee population requires all necessary support and interventions for a successful adjustment in their new environment and beyond.

As noted in the works of Roxas, ${ }^{14}$ Turrini et al. ${ }^{15}$ and Skleparis, ${ }^{5}$ the majority of refugee children in host countries are faced with challenges relating to their academics, psychosocial and economic well-being. Their separation from families, poor language proficiency, segregation, cultural dissonance, stress, different kinds of expectations between families and school management and limited financial means are some of the factors of concern. ${ }^{16}$ After their resettlement, the difficulties and challenges they encounter whilst navigating their new educational environment have a way of affecting their overall well-being. ${ }^{14}$ Investigating this has also become necessary in spite of the poor experiences and social challenges children from low socio-economic contexts, including children from refugee background, encounter in the primary school life., ${ }^{7,17,18}$
Studies and theories in the field of child development and child psychology suggest that the first few years of life for all children are critical for the development of the necessary skills including social skills needed to function well and be successful in school and beyond. ${ }^{19,20,21,22}$ Thus, this analysis will be approached from the perspective of Tinto's $\mathrm{s}^{23}$ integration framework and Bronfenbrenner and Morris ${ }^{24}$ bioecological model of development. This implies that the analysis will consider multiple influences such as the contexts of development, individual characteristics, socioeconomic status, experience and the processes of development and interaction over time. According to Tinto and Bronfenbrenner, these factors determine how well children integrate socially and academically into any system where they learn and develop.

Presently, whilst there is a plethora of researches that focus on the psychosocial, emotional and health well-being of refugee children in host countries and schools, ${ }^{25,26,27,28}$ there is limited research focussing particularly on the social interventions and integration of refugee children in the foundation phase school life in countries of first asylum. ${ }^{7,9}$ Thus, this article draws on the available research on refugee children's school experience and research pertaining to the social adaptation and intervention programmes for refugee children in countries of asylum.

\section{Towards a theoretical framework}

This article utilises Tinto's 1975 integration framework and Bronfenbrenner and Morris', ${ }^{24}$ bioecological model of human development as a lens for its analysis. Tinto sees effective social integration as that which occur when the conditions in the developing system is favourable and supportive of the individuals living in it. Tinto noted that both social and academic integrations are two variables that are dependent on one another. Thus, he asserts that, when a student is socially integrated into the life of the learning institution, their academic integration is enhanced and their performance is improved and vice versa. ${ }^{23}$

Bronfenbrenner and Morris, ${ }^{24}$ on the other hand, see an effective development as that which takes place in situations and contexts where different variables interact in a reciprocal manner for a positive outcome. Thus, Bronfenbrenner postulated that human development occurs because of the interaction between four essential elements, which are as follows: person, process, context and time (PPCT). So, he called his model the PPCT model. In this model, attention was paid to the daily interactions and inter-relatedness that occur between the developing person and others (the refugee children, their parents, teachers, peers and the community), the process of interaction and the context of the interaction (the school, the home and the community) over an extended period.

This article is premised on the understanding that for refugee children to adjust and be adequately integrated into the social domain of the foundation phase school life and 
thrive therein, it is necessary that they are exposed to quality and inclusive intervention programmes in the host schools, which allows them to interact with others and materials, in manners that are favourable to their overall development. This in turn will assist them to acquire the necessary social skills needed to develop optimally. As noted by Bronfenbrenner and Morris, ${ }^{24}$ human active participation in an interactive process over an extended period results in the development of ability, motivation, skills and knowledge, which help them to succeed in any context they find themselves.

Adopting the bioecological model of human development to understand the most effective social intervention for refugee children in the foundation phase school life requires that one pays attention to the significant persons that the children interact with alongside the context where they spend time to develop as equal determining factor of learning and developmental outcome. In this article, the theory is used to understand and analyse how the different interactions refugee children experience serve to assist them to have a smooth integration in the social life of the school. The theory describes the relations and interactions that exist between the developing person (the child), other persons (parents, teachers, siblings and significant others), the contexts (school, home, community and parent's place of work), objects and symbols (teaching, learning and play materials), taking into consideration the biological component of the developing person. ${ }^{11}$

Tinto's theoretical model on the other hand viewed the institution of learning as a social system encompassing its own value and social structure. Thus, Tinto asserted that, when students feel socially integrated into the life of the institution, their academic integration is enhanced which in turn leads to their academic success in the same institution. ${ }^{29}$ On the contrary, when students do not feel integrated into the academic life of the school system, their social integration is threatened and they eventually leave the institution. ${ }^{23}$ As mentioned earlier, Tinto noted that factors such as student's past experiences, ability, socioeconomic background, race and individual institutional commitment, interaction with peers, teachers, the academic and social life on ground in the school have a great impact on students' social and academic integration into the school system. Thus, we posit that for refugee children to have a successful integration into the social domain of the foundation phase school life in host countries, consideration must be given to the factors listed here.

\section{Experiences of refugee children in primary schools in countries of residence}

Refugee families in various host countries around the world are faced with multidimensional risk problems before, during and after their migration. Adjusting to their new environment and learning the local language is an ongoing challenge this group continues to combat with before its full integration into the new system. Research evidence suggests that the high increase in migration and human mobility has resulted in a host of challenges in schools serving children from diverse backgrounds. ${ }^{30}$ The ceaseless inflow of asylum seekers and refugees from different parts of the world meant that schools serving these populations must find an effective way of addressing the daily and ongoing challenges faced by this population if the sustainable development goals plan for 2030 is to be achieved.

Studies around refugees' resettlement and integration into their new countries of residence suggest that the refugee population are continuously faced with a host of barriers in terms of access to health, social and educational services which in turn pose multirisk problems to their overall well-being and survival. ${ }^{5,31,32}$ As pointed out by Rousseau and Guzder ${ }^{33}$ and Vostanis, ${ }^{26}$ the high exposure of refugees and immigrant families to hardship meant that they require all the support and interventions they can get in schools, but this is underutilised. Therefore, schools play a key role, both as mediators in the provisions of the needed services and helping children and youths adapt to their new environment and as the main access point for prevention and treatment services for mental health problems.

Evidence from research also indicated that refugee children's experience varies, depending on the country, the education policies and programmes on ground in such country. For example, Meda et al., ${ }^{34}$ Perumal $^{35}$ and Adams-Ojugbele ${ }^{11}$ noted that the difficulties around documentation and other social economic inequalities made it tough for refugee families in South Africa from securely accessing to the public schools for their children, including other services that support their resettlement process. This finding resonates with the findings from the work of Kirkwood, ${ }^{36}$ which suggest that different aspects of the asylum seeker system in the United Kingdom prevent effective integration of refugees and/or create barriers to their integration into school.

Furthermore, in the United States, research evidence suggests that the process of resettlement of refugee and asylum seeker families constitute a barrier to finding a suitable early childhood programme for their children. ${ }^{37}$ Morland et al. ${ }^{38}$ pointed out that in spite of research evidence that indicates the importance of providing equal quality of education programme to all children from diverse backgrounds, refugee and immigrant children tend to have a lower probability of participating in these programmes when compared with children from US-born parents.

In addition, findings from a study undertaken by Adebanji et al. ${ }^{39}$ indicated that the Zimbabwean immigrant children in the foundation phase in South Africa were able to adapt and integrate successfully into the social and academic life of their new school through quality interaction with their teachers, their proficiency in the language of teaching and learning and their ability to devise a means of communication with other peers in their new context. They also noted that 
parental support was remarkable in the children's school adjustment. Parents ensured that they communicated with their children in English, which is the language of teaching in schools. This led to the children's quick mastery of the language and in turn had a positive impact on the children's school adjustment and academic performance. To support this finding, Taylor and Sidhu ${ }^{16}$ found that the practices of inclusiveness, acceptance, respect and giving a sense of responsibility were noteworthy in both social and academic adjustment of refugee children in school.

The literature reviewed in this section indicated that the school experiences of refugee children are complex and varied. Whilst some refugee children enjoy inclusion in the foundation phase school life, others are faced with varied challenges, which impact negatively on their effective integration into the school system. The practices and policies of different schools are significant factors in determining the nature and quality of experience children receive. Countries globally devised different methods of inclusion and interventions to ensure effective adjustment and integration of refugee children into the school system. ${ }^{11}$

\section{Understanding the social integration of refugee children into the primary school life}

Acquisition of social skills is important for all children irrespective of their socio-cultural and ethnic background. This skill along with other school readiness skills assists learners to integrate effectively into the school settings for optimal learning and developments. ${ }^{40,41,42}$ The incidences of children entering the formal school with poor or lack of social interactional skills remain a major discourse in the literature. Compelling evidences have shown that children whose early years suffer in terms of the acquisition of social skills either from the home or designated preschools or early childhood centres find it difficult to cope with later schooling. ${ }^{40,41,43}$

Children from resource-poor contexts, including refugee children, constitute a larger population of children who find themselves at the verge of the society. The unfortunate incidences experienced by these group make it difficult for them to cope in school and beyond. Whilst many view the concept of integration as a one-way process, Castles ${ }^{44}$ saw it as a two-way street where both the refugee and the host society are expected to put forward an equal amount of effort for a desired outcome. In other words, whilst the newly arrived refugees make effort to adapt to the status quo in the host country, members of the receiving society must also adapt to meet the needs of the new migrants. ${ }^{44}$ Preparing an enabling environment that supports the needs of the refugee and asylum seeker population is a responsibility of the host country. Failure to do so might impact negatively not only the refugee population, but also the overall economic system of such a country.
For school-going refugee population, the school system serves as an important context where children acquire the necessary skills needed to survive in school and their new environment as a whole. Tinto ${ }^{45}$ and Karp et al. ${ }^{29}$ noted that individuals, generally in any system of learning, integrate effectively into the academic life of the institution when their social life in the same institution is positive. On the other hand, their academic life becomes threatened when they are uninvolved or do not participate in the social activities and life of the same institution. ${ }^{13,46}$ Thus, social and academic skills are two skills that are intertwined. Lack of effective integration in one domain might have a negative impact on the other. ${ }^{23,29}$

Informed by this understanding, it is expected that children in the foundation phase school life experience and are equipped with the needed social skills that will assist them in coping with later schooling because the foundation phase serves to prepare all learners for the social challenges of later schooling. For effective integration into the social and academic life of the school, it is necessary that the student interact effectively with teachers, peers and significant others in the school environment. Of major importance is the individual learner's willingness to participate and be involved in the activities around the school. This is believed to have a positive impact on learners' overall integration in the school system. Thus, social integration as referred in this review relates to the interconnectedness between students and the social domain of the school system. ${ }^{11}$

Findings from the work of Adams-Ojugbele, ${ }^{11}$ whilst investigating the Grade $\mathrm{R}$ experiences and school readiness skills of a group of refugee learners, suggest that factors such as children's socio-economic background, past and ongoing experience, the nature and quality of classroom interaction, teacher's classroom management style and teacher's professional development training all contributed to learner's effective integration into the school system. The findings from this study resonate with Tinto' ${ }^{47}$ postulation, which suggests that positive teacher-child-peer interaction constitute an important variable impacting children's social integration and overall school success.

Similarly, Pather and Chetty's ${ }^{48}$ conceptual framework suggests that the social integration of students in the learning institution is influenced by their socio-economic status, their past school experience, their individual ability and skills. These factors according to Tinto's postulation constitute a major determinant of how well students integrate socially and academically into their school system. ${ }^{11}$ Accordingly, Block et al. ${ }^{49}$ noted that schools play an important role in supporting refugee- and asylumseeking children's resettlement in schools. They noted that the school's ability to address issues relating to social exclusion, poor educational achievement, behavioural, mental and health problems is a viable means to tackle some of the problems faced by refugee children in schools. 


\section{Discussion}

The provisions of effective social intervention programmes that support the integration and adjustment of children in public primary schools are imperative for the actualisation of the sustainable development goal plan for 2030. . $^{1,50,51}$ Although different countries, governments, communities and non-governmental organisations have approached the provision of educational and social intervention programmes in different ways, with the aim of assisting refugee children in public primary schools and community-based centres have a successful adaptation into their new environment, the incidences of poor and inadequate social supports recorded in some public primary schools call for a redress.

The provision of quality social support for children requiring social needs, such as the refugees and the asylum-seeking children, is a complex responsibility requiring different stakeholders from diverse contexts coming together for effective implementation. The availability of developmentally appropriate resource materials, qualified educators and caregivers in a conducive and stimulating learning environment that targets the specific needs of this group becomes imminent. The increased level of research evidence on the incidences of mental disorders, ${ }^{15,52}$ in refugee children, including their risk factors, meant that a system has to be in place in all public schools and community based-centers serving children from refugee backgrounds. These systems are expected to assist refugee children in the acquisition of the needed social interactional skills ${ }^{41,53}$ and developing resilience skills, which assist them to cope and succeed in school and beyond. ${ }^{32}$

Furthermore, the prevalence of studies from post-conflict areas, including countries with newly arrived (asylum seeking) or resettled (refugee) children and young people, is noted. Most studies around the refugee population have focussed on post-traumatic stress disorder. ${ }^{2,26,40,54}$ There has been less attention so far paid to the role of the quality of attachment relationships, including those with extended family members. Unaccompanied children have an elevated risk of psychopathology and lower service engagement when compared with children who were accompanied by a family member during their migration. ${ }^{55,56}$

Thus, providing an inclusive social and academic environment that supports refugee children's ability to express their emotions, interacts with adults who are responsive and shows love, respect and care and provision of learning materials and interventions that attend to their specific needs are probable ways of assisting refugee children adapt to the life of the school. As noted by Tyrer and Fazel, ${ }^{57}$ the focus of most of the intervention programmes for refugee children included in their review is on children's posttraumatic experience, whilst noting that the school- and community-based interventions showed substantial improvements for cases of depression, anxiety, Post Traumatic Stress Disorder (PTSD), functional disturbances and peer problems. In addition, they noted that interventions such as inclusive programmes that target a school and home environment that promotes refugee children's school adjustment and adults who are responsive and supportive of children's integration into the school system are a sure way of assisting the refugee population to have a successful adaptation into the social and academic life of the school system.

In line with the studies reviewed here, successful adaptation of the refugee population into schools and their immediate community requires a joint effort of all stakeholders (government, community, teachers, the school management, school psychologists and parent or guardian) coming together to assist in the process of ensuring that like every other children, the refugee children are exposed to and experience relevant and specific intervention for holistic development and positive school outcome. For example, it is imperative that teachers understand the sensitivity surrounding the pre-migration experience of the refugee children in their care. They need to know and understand that some of the behaviour exhibited by these groups of children are potential outcomes of their past and ongoing experience as children from refugee background..$^{27,58}$

To help mitigate the negative effect of the post-traumatic experience of the refugee children, the teachers along with the school management are expected to create a traumasensitive school community with the help of a schoolbased psychologist who promotes and supports good relationship based on love, care and trust amongst teachers and students. This will assist children to self-regulate their emotions and behaviour that result into their success and holistic development ${ }^{40,59}$ and also promote their physical and emotional health. ${ }^{60,61}$

As argued by Bronfenbrenner and Morris ${ }^{62}$ through their bioecological systems theory, the different systems where the child lives and thrives directly or indirectly influence his or her development. He added that children's participation in an interactive process over time results in the child acquiring the ability, motivation, acquisition of knowledge and skills that assist them to participate and engage in different social and academic activities with themselves and others in their immediate and more remote environment. ${ }^{62}$

The school, the home and the community constitute the different systems that contribute to the holistic development of the child. Thus, the school that plays a bigger role in terms of the integration of the refugee children is expected to be conducive and supportive of the children's development. The roles played by different government policies and the prevailing culture in developing child's immediate environment cannot be over-emphasised. As pointed out in Bronfenbrenner's earlier writing, the role played by the environmental factors in supporting a child's development cannot be downplayed. It is imperative that the characteristics of child's immediate environment must be favourable to the characteristics of the growing individual; otherwise, an anomaly in the environmental factors might set a limit to the quality of the developmental outcomes. ${ }^{63,64,65}$ 


\section{Conclusion}

The focus of this article is to analyse some of the different intervention programmes available for the social integration of refugee children in the primary school life, where children live, and examine the roles played by the contexts (host countries and schools) in supporting a successful adaptation into the primary school life. In our sojourn, we found that the situation in different countries and schools differ. Whilst some countries and school management as well as teachers devised varied means to support the social and academic integration of refugee children in their schools, others do not have provisions to support the adjustment of these groups. The refugee legal frameworks that promote quality education and support the rights of the refugee children in some countries are poorly implemented or lacking. We also found that some schools do not have the system and personnel on ground to support the education and psychological well-being of the refugee population thereby exposing them to challenges that make it difficult for them to successfully integrate and adjust to the school systems in their host countries.

Our conclusions therefore are that a lot of actions still need to be taken to ensure that, like every other child, children from the refugee background are assisted to settle adequately into the school system with no hindrance. Programmes such as specialised teacher training that will assist teachers to implement a good classroom practice that supports and promotes the specific needs of refugee children are highly important. The presence of a school psychologist in primary schools, who attends to such children's psychosocial needs, becomes germane. An awareness programme to educate school management about the importance of creating a trauma-sensitive school community becomes imperative. It is believed that these analyses and suggestions will offer some guidance for governments and practitioners looking into supporting refugee children's effective adjustment and integration into their new environment.

\section{Acknowledgements Competing interests}

The authors declare that no competing interest exists.

\section{Authors' contributions}

R.O.A-O. was responsible for the conceptualisation and write-up of the article while N.M. author is the postdoc host and the critical reader.

\section{Ethical consideration}

This article followed all ethical standards for carrying out research without direct contact with human or animal subjects.

\section{Funding information}

This research received no specific grant from any funding agency in the public, commercial or not-for-profit sectors.

\section{Data availability statement}

The authors confirm that the data supporting the findings of this study are available within the article.

\section{Disclaimer}

The views and opinions expressed in this article are those of the authors and do not necessarily reflect the official policy or position of any affiliated agency of the authors.

\section{References}

1. UNHCR. Global trends: Forced displacement in 2018. Geneva: The UN Refugee Agency; 2018

2. Zimmermann A, Dörschner J, Machts F. The 1951 Convention relating to the status of refugees and its 1967 protocol: A commentary. Oxford: Oxford University Press; 2011

3. Twala C. An analysis of attempts by the United Nations High Commissioner for Refugees (UNHCR) in solving immigrants and refugees problem in the SADC region: A case of South Africa. J Hum Ecol. 2013;44(1):65-73. https://doi.org/10. 1080/09709274.2013.11906644

4. Moyo I, Nshimbi CC. Of borders and fortresses: Attitudes towards immigrants from the SADC Region in South Africa as a critical factor in the integration of Southern Africa. J Borderlands Stud. 2020;35(1):131-146. https://doi.org/10.108 0/08865655.2017.1402198

5. Skleparis D. Refugee integration in mainland Greece: Prospects and challenges. Policy Brief, 02, Yasar University UNESCO Chair on International Migration; 2018.

6. Alkhawaldeh A. Syrian refugees' children instructional challenges and solutions in Jordan: Teachers' and parents' perspectives. Border Crossing. 2018;8(2):311-331. https://doi.org/10.33182/bc.v8i2.448

7. Dryden-Peterson S. The educational experiences of refugee children in countries of first asylum. Washington, DC: Migration Policy Institute; 2015.

8. Aydin H, Kaya Y. The educational needs of and barriers faced by Syrian refugee students in Turkey: A qualitative case study. Intercult Educ. 2017;28(5):456-473. https://doi.org/10.1080/14675986.2017.1336373

9. Meda L. Refugee learner experiences. A case study of Zimbabwean refugee children. Hamburg: Anchor Academic Publishing; 2017.

10. Dalton-Greyling $T$, editor. Urban refugees: Definitions, legal positions and wellbeing in South Africa. Unpublished paper presented at the Annual Forum of the Trade \& Industrial Policy Strategy, held in Cape Town, South Africa; Citeseer; 2008.

11. Adams-Ojugbele RO. Refugee children's participation in a grade R program and their readiness for school: An ethnographic study. Durban: Durban University of KwaZulu-Natal; 2018.

12. Mweni SK. The right to education of asylum seeker and refugee children. Cape Town: University of Cape Town; 2018

13. Reynolds $A D$, Bacon R. Interventions supporting the social integration of refugee children and youth in school communities: A review of the literature. Adv Soc Work. 2018;18(3):745-766. https://doi.org/10.18060/21664

14. Roxas KC. Creating communities: Working with refugee students in classrooms. Democr Educ. 2011;19(2):5.

15. Turrini G, Purgato $M$, Ballette F, Nosè $M$, Ostuzzi G, Barbui C. Common mental disorders in asylum seekers and refugees: Umbrella review of prevalence and intervention studies. Int J Ment Health Syst. 2017:11(1):51 https://doi. org/10.1186/s13033-017-0156-0

16. Taylor S, Sidhu RK. Supporting refugee students in schools: What constitutes inclusive education? Int J Inclus Educ. 2012;16(1):39-56. https://doi. org/10.1080/13603110903560085

17. Bačáková M. Developing inclusive educational practices for refugee children in the Czech Republic. Intercult Educ. 2011;22(2):163-175. https://doi.org/10.1080/146 75986.2011.567073

18. Bourgonje P. Education for refugee and asylum seeking children in OECD countries. Educ Int. 2010;50:1-12.

19. Smidt S. Early childhood education and care for a shared sustainable world People, planet and profits. London: Routledge; 2018.

20. Schmitt SA, McClelland MM, Tominey SL, Acock AC. Strengthening schoo readiness for head start children: Evaluation of a self-regulation intervention. Early Childhood Res Quart. 2015;30(A):20-31. https://doi.org/10.1016/j. ecresq.2014.08.001

21. Dalrymple KA. Mindful learning: Early childhood care and development for refugee children in Tanzania. J Educ Emerg. 2019;5(1):133. https://doi. org/10.33682/37cx-3017

22. Arnett J, Maynard AE, Brownlow C, Chapin L, Machin T. Child development a cultural approach. Docklands: Pearson Australia; 2020.

23. Tinto V. Dropout from higher education: A theoretical synthesis of recent research Rev Educ Res. 1975;45(1):89-125. https://doi.org/10.3102/00346543045001089 
24. Bronfenbrenner U, Morris PA. The bioecological model of human development. In Lerner RM, Damon W, editors. Handbook of child psychology: Theoretical models of human development. Hoboken, NJ: John Wiley \& Sons Inc; 2006. p. 793-828.

25. Samara M, El Asam A, Khadaroo A, Hammuda S. Examining the psychological wellbeing of refugee children and the role of friendship and bullying. Br J Educ Psychol. 2020;90(2):301-329. https://doi.org/10.1111/bjep.12282

26. Vostanis P. New approaches to interventions for refugee children. World Psychiatry. 2016;15(1):75-77. https://doi.org/10.1002/wps.20280

27. Walker J, Zuberi D. School-aged Syrian refugees resettling in Canada: Mitigating the effect of pre-migration trauma and post-migration discrimination on academic achievement and psychological well-being. J Int Migr Integr. 2019:1-15. https:// doi.org/10.1007/s12134-019-00665-0

28. Horswood D, Baker J, Fazel M, Rees S, Heslop L, Silove D. School factors related to the emotional wellbeing and resettlement outcomes of students from refugee backgrounds: Protocol for a systematic review. Systemat Rev. 2019;8(1):107. https://doi.org/10.1186/s13643-019-1016-6

29. Karp MM, Hughes KL, O'Gara L. An exploration of Tinto's integration framework for community college students. J Coll Stud Retent Res Theor Pract. 2010;12(1):69-86. https://doi.org/10.2190/CS.12.1.e

30. Pinson $\mathrm{H}$, Arnot $\mathrm{M}$, Candappa $\mathrm{M}$. Education, asylum and the 'non-citizen' child: The politics of compassion and belonging. Basinstoke: Springer; 2010.

31. Washinyira T. Refugee children turned back by CapeTown schools. Cape Town, South Africa; 2019.

32. Meda L. Resilience among refugees: A case of Zimbabwean refugee children in South Africa. Child Abuse Res S Afr. 2017;18(1):62-69.

33. Rousseau C, Guzder J. School-based prevention programs for refugee children Child Adolesc Psychiatr Clin N Am. 2008;17(3):533-549. https://doi.org/10.1016/j. chc.2008.02.002

34. Meda L, Sookrajh R, Maharaj B. Refugee children in South Africa: Access and challenges to achieving universal primary education. Afr Educ Rev. 2012;9(Suppl. 1):S152-S168. https://doi.org/10.1080/18146627.2012.755287

35. Perumal J. Responding with hospitality: Refugee children in the South African education system. Educ Change. 2015;19(3):65-90. https://doi.org/10.1080/168 23206.2015.1085622

36. Kirkwood SM. 'Refugee' is only a word: A discursive analysis of refugees' and asylum seekers' experiences in Scotland. (PhD Thesis). University of Edinburgh. 2012.

37. Gross J, Ntagengwa C. Challenges in accessing early childhood education and care for children in refugee families in Massachusetts. Washington, DC Migration Policy Institute; 2016.

38. Morland L, Ives N, McNeely C, Allen C. Providing a head start: Improving access to early childhood education for refugees. Washington, DC: Migration Policy Institute; 2016.

39. Adebanji OT, Phatudi NC, Hartell CG. Factors facilitating the adjustment of immigrant children from Zimbabwe in the foundation phase to South African schools. Mediter J Soc Sci. 2014;5(3):512. https://doi.org/10.5901/mjss.2014. v5n3p512

40. Sullivan AL, Simonson GR. A systematic review of school-based social-emotional interventions for refugee and war-traumatized youth. Rev Educ Res. 2016;86(2):503-530. https://doi.org/10.3102/0034654315609419

41. Pinto Al, Grande C, Coelho V, Castro S, Granlund M, Björck-Åkesson E. Beyond diagnosis: The relevance of social interactions for participation in inclusive preschool settings. Dev Neurorehabil. 2019;22(6):390-399. https://doi.org/10.10 80/17518423.2018.1526225

42. Stanton-Chapman TL. Promoting positive peer interactions in the preschool classroom: The role and the responsibility of the teacher in supporting children's sociodramatic play. Early Childhood Educ J. 2015;43(2):99-107. https://doi. org/10.1007/s10643-014-0635-8

43. Neitzel C, Drennan K, Fouts HN. Immigrant and nonimmigrant children's social interactions and peer responses in mainstream preschool classrooms. J Educ Res. 2019;112(1):46-60. https://doi.org/10.1080/00220671.2018.1437529
44. Castles S. The international politics of forced migration. Development. 2003;46(3):11-20. https://doi.org/10.1177/10116370030463003

45. Tinto V. Leaving college: Rethinking the causes and cures of student attrition. Chicago, IL: ERIC; 1987.

46. Schreiber B, Luescher-Mamashela T, Moja T. Tinto in South Africa: Student integration, persistence and success, and the role of student affairs. J Student Affairs Afr. 2014;2(2):V-X. https://doi.org/10.14426/jsaa.v2i2.64

47. Tinto V. Leaving college: Rethinking the causes and cures of student attrition. Chicago, IL: University of Chicago Press; 1993.

48. Pather S, Chetty R. A conceptual framework for understanding pre-entry factors influencing first-year university experience. S Afr J High Educ. 2016;30(1):1-21.

49. Block K, Cross S, Riggs E, Gibbs L. Supporting schools to create an inclusive environment for refugee students. Int J Inclus Educ. 2014;18(12):1337-1355.

50. Nicolai S, Wales J, Aiazzi E. Education, migration and the 2030 agenda for sustainable development. ODI Briefing. London: Overseas Development Institute 2017.

51. Samuelsson IP, Park E. How to educate children for sustainable learning and for a sustainable world. Int J Early Childhood. 2017;49(3):273-285. https://doi. org/10.1007/s13158-017-0197-1

52. Sirin SR, Rogers-Sirin L. The educational and mental health needs of Syrian refugee children. Washington, DC: Migration Policy Institute; 2015.

53. Koehler C. Continuity of learning for newly arrived refugee children in Europe. European Commission. Gedimino: DG Education and Culture; 2017.

54. Hart R. Child refugees, trauma and education: Interactionist considerations on social and emotional needs and development. Educ Psychol Pract. 2009;25(4):351-368. https://doi.org/10.1080/02667360903315172

55. Chimbala-Kalenga R, Meda L. 'I will paddle my own canoe': Experiences of unaccompanied refugee children. J Hum Ecol. 2016;54(3):203-209. https://doi.or g/10.1080/09709274.2016.11907002

56. Popov O, Erik S. Facing the pedagogical challenge of teaching unaccompanied refugee children in the Swedish school system. Probl Educ 21st Century. 2015;64:66-74.

57. Tyrer RA, Fazel M. School and community-based interventions for refugee and asylum seeking children: A systematic review. PLoS One. 2014;9(2):e89359. https://doi.org/10.1371/journal.pone.0089359

58. Subedi A, Edge DS, Goldie CL, Sawhney M. Resettled Bhutanese refugees in Ottawa: What coping strategies promote psychological well-being? Can J Nurs Res. 2019;51(3):168-178. https://doi.org/10.1177/0844562119828905

59. Stoessel K, Titzmann PF, Silbereisen RK. Children's psychosocial development following the transitions to kindergarten and school: A comparison between natives and immigrants in Germany. Int J Dev Sci. 2011;5(1):41-55. https://doi. org/10.3233/DEV-2011-11077

60. Harmon $\mathrm{H}$, Initiative $\mathrm{CR}$. Supporting and including refugee and asylum seeking children in education. Dublin: National Centre for Guidance in Education; 2018. p. $1-20$.

61. Busch J, Bihler L-M, Lembcke H, Buchmüller T, Diers K, Leyendecker B. Challenges and solutions perceived by educators in an early childcare program for refuge children. Front Psychol. 2018;9:1621. https://doi.org/10.3389/fpsyg.2018.01621

62. Bronfenbrenner $\mathrm{U}$, Morris PA. The bioecological model of human development. In: Lerner RM, Damon W, editors. Handbook of child psychology: Vol 1: Theoretical models of human development. 6th ed. Hoboken, NJ: John Wiley \& Sons; 2006. p. 793-828.

63. Bronfenbrenner U, Morris PA. The ecology of developmental processes. In: Damon W, Lerner RM editors. Handbook of child psychology: Vol 1. Hoboken, NJ: John Wiley \& Sons Inc; 1998. p. 993-1028.

64. Ceci SJ. Urie bronfenbrenner (1917-2005). American Psychologist. 2006;61(2):173-174.

65. Bronfenbrenner U, Evans GW. Developmental science in the 21st century: Emerging questions, theoretical models, research designs and empirical findings. Soc Dev. 2000;9(1):115-125. https://doi.org/10.1111/1467-9507.00114 